\title{
Governing Alternative Resources for Social Policy: A Welfare Political Challenges on Mixed-Welfare Arrangements
}

\author{
Tauchid Komara Yuda•
}

\begin{abstract}
The issue of social policy development in Indonesia has received considerable critical attention due often not consider non-state actor in the welfare provision. Data from several studies show that welfare system of contemporary Indonesia commonly fits with mix regime model, where the state, kinship relation, and markets play important role in provide social welfare for the society simultaneously. Accordingly, the greater efforts are needed to ensure that policy maker could regulate the ability to stimulate the compatible actor with likely welfare outcomes expected. By taking the empirical case of the Program Bedah Rumah Swadaya in Kulon Progo Regency Yogyakarta, this paper would examine the welfare politics that put community and market institutions as alternative resources to provides the decent houses for disadvantage groups. Correspondingly, this account composed into the three of main parts. The first part begins by laying out a brief overview of the foundation of Kulon Progo welfare system. The second part would identify how the political citizenship dimension is carried out through this programs. While the last part captures the resource arrangements in housing provision.
\end{abstract}

\section{Keywords:}

social policy; welfare politics; program bedah rumah swadaya; alternative resources.

\section{Introduction}

There is a growing significance issues on set of social policy development in Indonesia related to misintersection problems between state functions in order to fulfillment and financing of public goods for society (Ikhsanto, 2008; Mas'udi and Hanif, 2010). The fulfillment functions is referring to state obligation on establishing policies which underpin both social and economic security to stave-off social risk when insecurity and uncertainty came to. Meanwhile, financing functions is a political personification of the state to the society through a welfare budgeting scheme. The policy problem has begun to emerge when the welfare demand increased, but the government fails to deliver on entitlements to citizens by the comprehensive schemes of coverage such: preventable, affordable, and reach to basic needs (Dukelow, 2011).As the consequence state responsibility only reaches the fewer society. Accordingly to overcome discrepancy between state ability with wide range of the existing welfare demands, the goverment should paying special attention for 'alternative institutional devices' to meet the challenges by shift the burden upon procurement of well-being to intra-family support/community based-charitable or private sector schemes (or individual scheme through social insurance)

\footnotetext{
- Department of Social Development and Welfare (PSDK), Faculty of Social and Political Sciences, Universitas Gadjah Mada \& Social Policy Club (SPC) member.

Email: yudo.ugm@gmail.com
} 
(Croissant, 2004; Moreno, 2010; Shi, 2016). Each of scheme has distribution path which different one another. Community or family supports are reciprocity based. In contrast, the private sector is governed by distribution through the cash nexus. While state takes the form of authoritative redistribution (EspingAndersen, 1990: 35-36). As Hall and Midgley (2004) stated "notions of what constitutes social policy have moved from the statutory provision of social welfare, either under a minimalist, residual (selectively) model or through a more systematic".

Thence, ideally, policy maker should pay attention to context, commitment, and capacity (Kabeer, 2004 cited in Martono, 2008: 25) as consideration in determining of welfare distribution methods. The context related to policy analysis, politics, macroeconomic, culture, demographic, and social differentiation. The so-called commitment is associated with social vision as guidelines for directing and implements development project. While capacity linked with state political commitment to reshaping the vision into the social development practices. The capacity not only addressed to state financing for social welfare, but regulating the ability to stimulate the compatible actor with likely welfare outcomes expected by state. Therefore, a determinant factor of social policy management is identifying non-state actor which having synergy with politicaleconomy for social welfare as well as involves voluntary organization and private sector into welfare distributions (Hujo and Mcclanahan, 2009; Kwon, 2009; Meeuwisse and Swärd, 2009; Norton, Conway and Foster, 2001; Schartau, 2009).

A several of studies (Aspalter, 2006; Croissant, 2004; Gough, 2013; Rodhes and Natali, 2003; Powell and Barrientos, 2004; Sumarto, 2017; Torheim, 2013) have provided important information that the welfare system in Indonesia are common fits with complex connectivity ${ }^{2}$, that means, state, kinship relation, households, and markets can provide social welfare for the society simultaneously. Gough in his account $(2004 ; 2013)$ proposed this sytems called as mixed welfare. This phenomenon can be understood by tracing the economic and social formation in Indonesia which has been created different way from the West path. First, informal economies within peripheral capitalism commonly found in Indonesia which result in creates uneven development. Second, a portfolio of livelihoods depends on subsistence economic, peasant agriculture, artisant, self-employment, informal-employment as well as informal relations. Third, state weakly differentiated from other power system (Gough, 2013). That argument explains why the informal relation a widely range of the institutions and actors still involved in social welfare provision. Unlike the industrialization in the West, where the blossoming of capitalism came with withering away of traditional social security (EspingAndersen, 1990: 35), then replace it with an individualistic society, subsequent creates division of labour based on the ownership of the capital. Therefore the management of social risks relied on the market or the state. From these explanations, it can be understood that the existing welfare resources in Indonesia potentially to be collaborated in the distribution of social welfare-as the following case in Kulon Progo Regency, Indonesia.

\section{Program Bedah Rumah Swadaya: A Mixed Welfare Representation}

In the last five years, calculated from 2010, Kulon Progo Regency identified as one of highest poverty regions in the Special Region of Yogyakarta. In late 2010, the percentage of the population under the poverty line in

\footnotetext{
${ }^{2}$ In term of welfare regime studies, it was known as welfare mix regime, as revision of the Gøsta EspingAndersen at the earlier, in his book entitled The Three Worlds of Welfare Capitalism (1990).
} 
Kulon Progo has reached $23.15 \%$ over the percentage of other regions as: Gunung Kidul $(22.05 \%)$, Bantul (16.09\%), Sleman $(10.70 \%)$ and Yogyakarta (9.75\%) (TNP2K, 2011: 7). Although in 2011, the percentage of poverty increased to $23.62 \%$ (TKPK Kulon Progo, 2014: 12). To respond its situation, then Hasto Wardoyo-who at that time just beginning to the first period as regent- started doing the data collection of poor families who are expected to render the real picture of the condition of the poor household in Kulon Progo Regency. The poverty data collected is used as a guide to goal setting poverty alleviation program. Four of the 16 poverty indicators listed in regulations of Regent No. 39/2011 about local poverty indicator derived by the Program Bedah Rumah Swadaya (house renovation programs). While the 12 poverty indicator remaining, reduced by the other multifunctional schemes such as: no class hospital policy, toko milik rakyat (tomira-community owned general strore), and the other programs that also involves multi stakeholder. ${ }^{3}$

More limited economic resources for housing policy drives the way for more pluralistic arrangements of Program Bedah Rumah Swadaya. This program build on a special features of the mixed welfare of private (CSR - Corporate Social Responsibility fund), individual, public and voluntary organizations, and the implementation is carried out by the community participation united by moral purpose, voluntarily fulfilling the right to those less fortunate. This case remarks out that private-public welfare mix as the alternative means for the procurement

\footnotetext{
3 These innovative programs have been reduced the poverty in Kulon Progo significantly. A year later, (2012), percentage of poverty in Kulon Progo was reduced to $23.32 \%$ compared to previous year $23.61 \%$ (TKPK Kulon Progo, 2014:12). In 2013, poverty decreased again to touch the numbers 21, 39\% (BPS Kab. Kulon Progo, 2013:75) and continued to decline until 20.64\% in 2014 (BPS Kab. Kulon Progo, 2016) and then become 16.98\% in 2015 (Kulonprogo.go.id 2016).
}

of social services (Moreno, 2010) 'has become a promising avenue to redress the government insufficiency as well as stimulate a public sector more responsive to social needs' (Shi, 2016: 464). In another account (Schartau, 2009; Warington, 1995) refined the mixed-welfare term as welfare plurarism which both of these are used interchangeably. In short, these term refers to decentralized of welfare service with 'far greater community orientation' (Schartau, 2009: 3) as a response global political-economic change on the edge of $80 \mathrm{~s}$.

The most surprising aspect should be highlighted is, the ideological of Program Bedah Rumah Swadaya is displaying out the liberal discourse based on communitarian preferences. The liberal discourse can be identified from, goverment welfare expenditure designated minimal as well as recipient are means-tested based on entitlement (selective/residual), rather than provide a framework for addressing the right of citizen. Nonetheless, this residual system having different ways from other residual system in general as follows: First, subsidy of the house renovation program ( Rp10.000.000,00 per household) were taken from the nongovernment budgetary, and the role of the government as a regulator and facilitator only. Concomitantly, non-state actors, such as charity organizations and private interests are secondary and suggest to participate in this program under the supervision of government rules (Mas'udi and Hanif, 2010. Second, when a lot of residual programs arose the social conflict ${ }^{4}$, but this program renders the opposite impression. The reason is the beneficiaries determination system was held by the citizens at the grassroots level through the informal consensus mechanism (musyawarah), thus in its

\footnotetext{
4 As Beras Miskin (Rice for the Poor Program), Unconditional Cash Transfer (BLT), and another resiudal programs, which often triggers conflict between society and local government as well as conflict among people, thus lead to detriment of social capital (Sumarto, 2007; Sumarto, 2014).
} 
implementation has carried out by relying on kinship relation in the form of gotong royong. ${ }^{5}$ While the government take role as verificator only and making sure the beneficiaries deserve the program, thus can stave off social conflict during distribution. This way was chosen by considering the communitarian values which have been embedded in Kulon Progo culture and society, henceforth absorbed as integral parts of the program implementation, as would be discussed later in this paper.

Based on the explanation above, this article would assessed by the research question: how the government organizing the existing elements of welfare institution within housing renovation provision? To answer the question followed, the remaining part of the paper proceeds into the three of parts. The first part (after research methods) begins by laying out a brief overview of the foundation of Kulon Progo welfare system, which would showcase how the existing institution affects to inject a series of regulations in the form of norm and value in policy was produced. Turning now to the second part, this section would be concerned with discourse appeared of this program, as well as identify how the dimension of citizenship political practices is carried out which both were shaped and affected by fundamental value underpinning systems related to local welfare preference.

The third part captures the resource arrangements in housing provision. The author presents the form of deployment of the resources that are used as the underpinning of the financing program, including political debate which colouring over the resource allocation process for the program. Resources used is derived from religion charitable organization, CSR, and voluntary based/ institutions/individuals. The three path of each sequence will emphasize the functions of

\footnotetext{
5 It reflect to communal values of Indonesian society that emphasize 'working together to achieve common goals' (Joedadibrata, 2012: 16).
}

sustainability, inclusivity, and put participatory self-help as the main function of the program.

\section{Methods}

This study based on qualitative methods, with variants of case studies. A case study approach was used to enable author to answer the research question in regard with 'how' and 'why' (Yin, 2003 cited in Baxter and Jack, 2008: 544). Given the issues raised in this study aims to investigate and understand the complexity of the rules (Creswell, 2013: 137) of Program Bedah Rumah Swadaya, which is then breakdown into the discussion. Data were gathered from two of phases: first, observation throughout June - July 2016 over the updated issues of the Program Bedah Rumah Swadaya at the local mass media and pre-research visit. These observations were conducted to grab the preliminary information related programs, thence map out what topics will be author discussed.

Second, fieldwork research was conducted for two weeks (during August) in Kulon Progo regency by interview and looking for supporting documents such as: data report of cash flow the program, beneficiaries, and local regulation. For more structured interviews I use purposive sampling model, or also called judgmental sampling. This technique used to determine information by way of taking key informants only suit the research purposes, and are able to represent the interests influencing the programs, such as those who has the knowledge, capacity and, or specific role in the policy production. Based on these reason, I consider to conducted interviewing with: Regent of Hasto Wardoyo, special staff of government, head of social welfare division (Kesra) who supervising the program, staff of BAZNAZ Kulon Progo, public relations officer of the Christian Association - which also at one time served as staff of the CSR forum of Kulon Progo, and having good knowledge about the process of funding program - representatives 
of one of the largest cigarette company CSR in Kulon Progo, and village in chief of Giripeni and Bendungan. To complete the research findings, the author has also interviewed mass organization such as Nahdatul Ulama (NU) Kulon Progo branch and Muhamadiyah (represented by the head of hikmah and public policy divisions). The both of mass organization are suitable as a representation of public opinion related to the program. In addition, these of both institutions is also the largest civic organization in Kulon Progo.

Informants were interviewed to clarifies the statement of Regent policy, and other information, which can consider as material for analysis. The final stage of the study compares the statements found during the interview with a various existing documents, to ensure that research objectives are in alignment with what would want to be accomplished.

\section{Results and Discussion}

\section{The Foundation of Kulon Progo Welfare System}

Inevitably, in the Kulon Progo society traditions, the individual well-being, and social risk management most of relied on community charitable, rather than the state and market due they have not sufficient access to reach of both. This scheme ensures community as a whole supported the welfare of its members (Lewis, 1999). In a citizenship perspective, such exemplify are referred to as communitarian citizenship (Isin and Turner, 2002: 3 -4). This informal network formed and working based on an exchange of produced continuously, and always expect one another (reciprocal assistance). For those got benefit from the scheme, automatically they bounded owe to another individual in other forms that may imbalanced if calculated by material (Suharko, 2005: 275).

Beyond tradition factors, the existence of the third sector which affiliated religious organizations in Kulon Progo played a major role in providing social welfare for society. Such as the local Catholic Church networks, Nahdatul Ulama (NU) and Muhamadiyah which had focused towards the fulfillment of decent house for the poor since a long time ago. The Catholic Church network, which supported by the Semarang dioceses, become active actors in the house renovation activities for their congregation who less fortunate. But this house renovation trends have not been entered priority agendas, than the other programs like: health assistance and/or education assistance for students.

Correspondingly, house rehabilitation/ renovation activity has also been carried out by a few of private sector through CSR activities since 2004. But, the coverage of its distribution remains limited to active employees who work at the company only.

In general, the pattern of implementation, the approaches, and design in related to house renovations activities neither it by third sector or privat sector emphasizes the partnership or collaboration. The role both of the third and privat sector just giving some sort of fiscal stimulus, while the other supporting complementary aids such as manpower, material for constructions, as well as other needs that have not been covered, are collected from those are caring (kinship networking). This kind of scheme fosters a spirit of kinship and mutual assistance in an attempt to distribute the decent house for those less fortunate. Such exisisting house renovation/rehabilitation traditions was later "layered" with the formal institution namely "Tresno Tonggo" programs by former Regent, Toyo Dipo Santoso, on top of existing tradition without resulting in substantial change on the traditions (Sumarto, 2017). Nonetheless, it was not comprehensive, but flooring project only. After Hasto Wardoyo served as Regent in 2011, the former house renovation program was improvised and renewed with new flag namely "Program Bedah Rumah Swadaya." 
The Kulon Progo government have consistently recognized the importance of the third sector and informal networking as parcel of the body politic of the welfare. The program became got the public attention widely, because it has fostered citizen participations, without government budgetary, then claimed to be the flagship program of Hasto regimes.

In further discussion, what has been practicing by Kulon Progo goverment is closely with "participatory welfare" conception, where the main idea of this scheme emphasizes welfare community state through the participation of citizens as well as make a firm commitment to achieve their shared vision. As Chan (2006) holds the view that participation in this term can be referred as "individuals and communities participating in providing and managing welfare to those in need, which is, in fact, constructed as their obligations". At the same time also re-emphasizes the traditional family and individual's norm in policy implementations.

\section{Welfare Politics and Discourse Mapping}

In accordance to Hanif (2012), social policy is a narrative of the construction project of citizenship or social formation. Or rather, the social policy practice is the reflect of citizenship or social formation imagined by the policy maker. However, the proper social policy should appropriate with social formation forms in where it would apply. As the following explanation, which the author took samples from comparative discourse between liberal citizenship and republicanist citizenship.

In the liberal citizenship, autonomy and fundamental rights -encompasses freedom, dignity, and expression-inherent in each individual. The liberal society believes the truth upon these fundamental rights. They are not only enjoying it solely but rather participating in retaining so that they can keep on enjoying it in various aspects (Suleman, 2010: 99). Thus logically, the character of social policies scheme later should be a deal within individual norms, by the government should withdraw from the welfare intervention as a form of reverence for the individual rights. In contrast to the republicanist citizenship, where they tend to homogeneous cultural (Tribowo and Bahagijo, 2006: 44) and egalitarian have affected in forming of the relationship of the State and its citizens are intimate. Selle and Kuhnle called it as state friendliness (Kurniawan, 2009: 73). This pattern of citizenship relations affect the creating process of social policy laid on the three major of social foundations. First, inter-class solidarity which presupposes that all people do not have differences with each other. Second, making sure all society have equal access to the public goods is the main goal. Thrid, social immunization from market commodifications (Hanif, 2008; 2012). Third of this point would lead to welfare politics against the market (decommodification) (Esping-Andersen, 1985) to relinquish citizen from dependence on the institution or the market norms in accessing social-welfare, by making its a right of every citizen universally (Esping-Andersen, 1990). In that way, the encouragement of government intervention in social welfare is legitimated, even deservedly. This power relation form is referred to as protectionism. Notwithstanding should be remarked, this comparative not address to apply the logic without modifications. However, both of the logic are devoted to western institutional analysis which cannot accommodate the emergence of Asian welfare systems which democratic and capitalist institutions are rudimentary (Walker and Wong, 2005). In further discussion of this context, what and how the power relationship works among the citizen and the state in the Program Bedah Rumah Swadaya?

Surprisingly, author was found the different power relation path, where liberal discourse blend with communitarian at once, which is reflected clearly in the process of policy 
productions. The liberal discourse of the scheme may confirmed by identify of local government budgetary $(A P B D)$ of housing renovation is minimal. This situation was had maintained throughout almost four years running without intention to financed through $A P B D$. Hanif and Mas'udi (2010: 113 - 144) argues it reflects that the logic non-inclusiveness is dominant, means, the government will only intervene and assist groups of citizens with social problems and potentially vulnerable groups.

Nonetheless, the government confirms that communitarian discourse is the basis to define Kulon Progo citizenship. This can be understood considering the role of the community can be a complementary or alternative for welfare distribution. Moreover, communitarian values which still prevailed has formed a preference of actors to public policy. The communitarian discourse is emphasized through political populism of Hasto which attempted to shape a discourse to confirms that "kinship, collectivity and familianism" are Kulon Progo identity to confronting individualism. He reshapes the discourse about the communitarian understanding beyond of "livelihood" or "neighborhood" boundaries. It articulated within the "Gentong Rembes movement" (Gerakan Gotong Royong Masyarakat Bersatu), it means, unity for achieving the common goal. Philosophically, "gentong" refers to a water cistern. The water in that cistern subsequently permeated (dirembesi/merembes) to around, then its benefits can be distributed for those needy (interview with Jumanto, a staff expert on governance, September 2, 2016; RHP, August 3, 2016). This philosophy having provided the fundamental principal underpinnings for program success by promote collectivism and lifting the spirit of sharing.

Gentong Rembes movement was introduced early to local entrepreneurs, NGOs, and all middle-class group in Kulon Progo. The initial approach used by Hasto was charity concept for the poor. Where the charity fund accumulated was distributed through government welfare programs, including which is Program Bedah Rumah Swadaya.

Nevertheless, the strategy has not escaped criticism from contradictions problem between the residual discursive as policy formulation with the existing social formations in Kulon Progo.

Although this contradiction discursive can be overcome by the anthropology of bureaucracy (Heyman, 2012), where in this process, the government emphasizes an important role in constructed the citizen identity as the object (and subject at once) of power in ways that are not realized by a citizen. Even the government is able to disguise its the policy, and give the impression, as if it is an authentic citizen initiative (Zuska, 2005: 154 155). This ultimately encourages the enthusiasm of society to participate. The Kulon Progo citizens were constructed to imagine that this program was initiated by citizens, for citizens, and governed by the citizens -more detail will be discussed at sub-chapter in related about distribution topic. Due to the authority in order to determine the beneficiaries, is conducted by the citizens directly, not by the government. Correspondingly, the concept of individuality becomes faded away. The mechanism has dissolved the boundaries of individuality into the landscape of the communal. It affected to appearing community responsibility to help beneficiaries because they feel that the individual beneficiaries result from musyawarah. As Javanese philosophy: usul-mikul. This term is other forms of the existing communitarian values in Java, that rule is an expression of the society willingness (Menoh, 2015: 73). In turn, it demands society have a moral obligation to obey as their consequence in the local politic institutions where they aspire.

This fact makes the power relations that lasted a disembodied shadow state (Warington, 1995), in which the government authorities are facilitators. It described the relations of power 
that was built the government to its citizens is a liberal model partially. The government withdraws the responsibility in providing livable houses for the poor to the alternative sector which controlled (intervened) by the government in both of production and accumulation.

In another term, the government model as described above is also known by the term of governmentality (Gustomy, 2010: 18). Governmentality is a political concept to explain that power is not 'ownership,' but related to how to create good citizens and controlled them softly. The limitation of the social budget is often used as a reason for the government withdraw their responsibility. Thus, the public goods fulfillment is charged to the public. To get liaison to operate, the government creates various settings that can mobilize the community participation to comply with everything towards has regulated hegemonically (Gustomy, 2010: 18). As Foucault stated, that the effectiveness of power thus lies in its ability to hide power and its mechanism (Zuska, 2005: 154 - 155)

\section{Resource Arrangements in Housing Provision}

In this section, the author will concern to how discourse produced previously redistributed into the ways of resource organizing for the program, which is divided into three lines. The first line is intervention by the informal approach to suggest institutions based on local religion such as National Agency for Amil and Zakat, Branch of Kulon Progo Regency (BAZNAZ Kulon Progo) to optimize the function for welfare as a line with government goals, one of the function is the house renovation. Together with BAZNAZ engagement, the government was also initiated to forming Christian Employee Association which was directed to support government welfare program.

The optimization of BAZNAZ Kulon Progo functions was started by program synergization through negotiation between BAZNAZ Kulon Progo with government poverty reduction agenda. The results agreed upon "informally" (no MoU) cooperation in the Program Bedah Rumah Swadaya. This collaboration puts the government as regulator and undertakes mean-tested for beneficiaries, whereas BAZNAZ Kulon Progo as funding supports and categorized the beneficiaries for those Muslim only (interview with Supardi, Staff of BAZNAZ KP, 3 August 2016).

Most of the zakat funding is collected from Muslim civil servants. This way was chosen considering that zakat from Muslim civil servant of Kulon Progo can reach Rp. 150 million per month -from previously $\mathrm{Rp}$. 200 million per year only. The remarkable of Hasto achievements in optimize of zakat funds inseparable from the 'deconstruction' of the zakat understanding by Hasto government. Generally, the zakat has been understood as 'the religious obligatory paid by Muslims on annually contribute a portion of their wealth once it has reached the threshold (nisab)' (Halimatusya'diah, 2015), to then given it to a certain category of a group called asnaf. All the Islamic jurist revealed firmly that zakat as a religious obligation. It was attested by the Quran (QS. Attaubah: 103), in which God commanded the Prophet to collect zakat from Muslim those able to pay the zakat and redistribute it to the asnaf (Ibrahim, 2015: 437). The nominal zakat to be paid generally refers to $2.5 \%$ of the value of property owned by a Muslim.

One interesting finding is the government has 'deconstructed' the zakat concept by emphasizing: zakat was compulsory for Muslims, to enhance awareness of the Muslim civil servants, government give zakat payment facilities through BAZNAS Kulon Progo partnership, then would distribute it to the poor through government welfare programs -one of which is Program Bedah Rumah Swadaya. There are no formal instructions for the Muslim civil servants to pay zakat to the 
BAZNAZ Kulon Progo, but only in the form of advisories and letter ability to pay zakat for those are willing. Surprisingly, there is no minimum threshold of the amount of zakat are paid per month and no refer to a provision of 2.5\% (interview with Jumanto, a Staff Expert Governance Kulon Progo, September 2, 2016, and Supardi, Staff/Trustees BAZNAZ Kulon Progo, August 3, 2016).

Furthermore, the Christian Employee Associations through the persembahan funds also contribute to supporting the program. Roughly, the operating model of this association in line with BAZNAZ Kulon Progo. Indeed, the intensity of its contribution not as many as BAZNAZ Kulon Progo that targets at least 3 houses per month, due to the Christian population at Kulon Progo are minorities. These associations were formed in response to the concern of the Christian people - either the Protestant or Chatolic - for their congregant who live under the poverty line.

Should be admittedly, the religious organization involvement to support welfare programs can be claimed as powerful instrument designated to combating poverty and inequality. Because there is an intersection between religious value and government goals in relation to poverty alleviation. In addition, it can be understand sociologically, that poverty alleviation in the religious organization has embedded as value-rational action. By these means, the action was understood as the "absolute value" and "final value" for individuals, who considered consciously (Damsar, 2012: 36). Furthermore, there is also the factor of trust to institutions that represent the religious symbol because considered can reflect to rely heavily close with transcendent responsibility which believed to reduce the chances of abuse of authority (Suparjan, 2010: 12). This assumption can strengthen the public trust to religious institution managing in the public fund, rather than the government. Hence it is logical if the funding circulation of the program based on religiosity would be sustainable, as long as the religion is still a binding instrument of the society. Likewise, there are many challenges facing policy makers if they are only relying on religious schemes in program supports because often it can not be separated from primordial issues,

Diagram 1.

CSR Allocation for Public Agenda in 2015

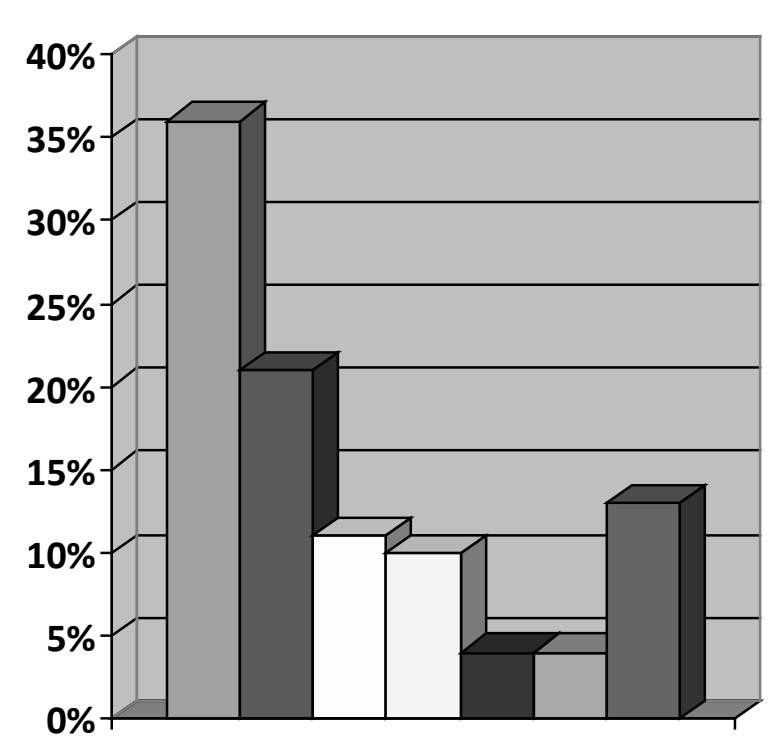

Source: CSR forum report, 2016

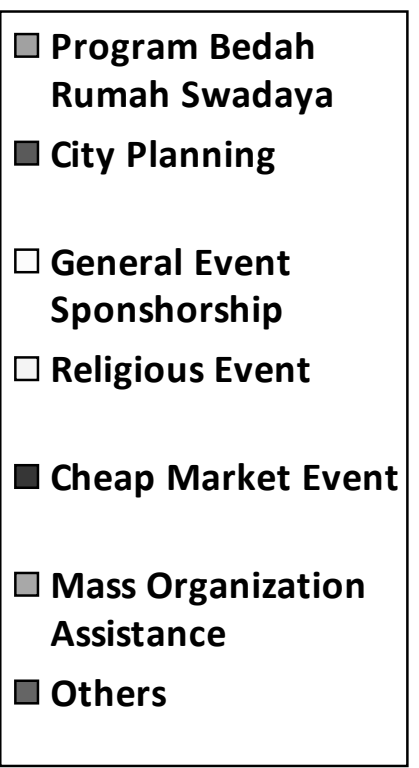


nor the political identity as well. The effect is, beneficiaries consideration tend to primordial preferences, rather than needs. Actually, Program Bedah Rumah Swadaya has been accepted as a "public agenda." Reffering to Cobb and Elder (1972 cited in McClain, 1990), the so-called public agenda is entire of all issues that are commonly perceived by members as well as receive widespread attention or at least awareness. Thus, of course, the things are recognized as publicly, however, should adhere the inclusiveness principle rigor. At this point, the government must to looking for another resource, such as involving the company sector and individual or institutional.

A second line is company sector approach. The companies participating in the program is run by the CSR forum. CSR forum is a CSR association both of a local government-owned company (BUMD) and the private company which has a secretariat under the auspices of the Kulon Progo government. The institutional status of the forum of CSR is quasi-formal. Politically, such institutional status is tremendously strategic for controlled and mobilized by the government, as proven from data findings have that shown the largest proportion of CSR in 2015 has allocated to support house renovation program (36\%).

There are important things that should be underlined, nonetheless the fact that CSR does not guarantee the sustainability, but it prospective as long as an investment is running on. Increasing of the investment would increase CSR funds accumulation as well.

The government's strategy to directing a company to merge the CSR schemes within the government program is also by advisories approach and letter of ability to pay. In practice, the majority of companies which are incorporated in the CSR forum is BUMD (Data penerima manfaat RS RTLH non-APBD, Setda Kulon Progo, 2016). It obviously to understands because $B U M D$ has institutional relations under local governments. On contrary, many private companies perceive that CSR forum mechanism is considered bit disadvantage either politically and economically. It can be understood by identify corporate interests to CSR. First, CSR used as a safety net for companies to stave off the objection from the affected group in around of extraction area. Second, the CSR put as part of production cost, then it is logical if it should also serve as an instrument in order to maximize profitability by used CSR as part of marketing strategy (Yuda, 2016:205). Both of these functions would decrease if the company have to deal with the CSR forum due to: (1) if the some of CSR funds transferred to the government program, it would reduce the function of the safety net in the area of extraction, thus increasing the company vulnerability levels towards the conflict from the group affected. (2) CSR forum perceived not representing the existence of the company as a whole, but government benevolence more.

The third line is relied on voluntary/ individual/institution as well as welcomes the private sector engagement. In this schemes, the government was more likely to facilitate for those who willing to distribute funds to beneficiaries rather than to intervene politically. For the private companies, this scheme may consider as the best choice for advertising or marketing at once rather than the second line, because of the assistance provided is not claimed under the CSR forum flag. Therefore, by choosing the third line, the private company

Table 1.

Annual Investment Report of Kulon Progo Regency (IDR)

\begin{tabular}{ccccc}
\hline $\mathbf{2 0 1 2}$ & $\mathbf{2 0 1 3}$ & $\mathbf{2 0 1 4}$ & $\mathbf{2 0 1 5}$ & $\mathbf{2 0 1 6}$ \\
\hline $\mathbf{4 3 0 . 5 5 5 . 0 3 4 . 2 4 9}$ & 983.363 .175 .249 & 1.374 .519 .280 .374 & - & - \\
\hline
\end{tabular}

Source: Development Planning Agency (Bappeda) of Kulon Progo Regency, 2015 
get advantageous for branding, but also did not withdraw their commitment to supporting government programs. The third line has put

Table 2.

Total of Accumulation

of Voluntary Funds and Total Amount of Program Bedah Rumah Swadaya

Beneficiaries

\begin{tabular}{crc}
\hline Year & $\begin{array}{c}\text { Total of accumulation } \\
\text { of voluntary funds (in } \\
\text { Indonesian Rupiah) }\end{array}$ & $\begin{array}{c}\text { Amount of } \\
\text { program } \\
\text { beneficiaries (in } \\
\text { Household) }\end{array}$ \\
\hline $\mathbf{2 0 1 2}$ & $1,595,155,850$ & 188 \\
$\mathbf{2 0 1 3}$ & $823,000,000$ & 93 \\
$\mathbf{2 0 1 4}$ & $1,083,495,000$ & 94 \\
$\mathbf{2 0 1 5}$ & $1,070,000,000$ & 110 \\
$\mathbf{2 0 1 6}$ & $970,000,000$ & 97 \\
\hline Total & $\mathbf{5 , 5 4 1 , 6 5 0 , 8 5 0}$ & $\mathbf{5 8 2}$ \\
\hline
\end{tabular}

Source: Regional Secretariat (Setda) of Kulon Progo Regency, 2016 emphasis on the functions of sustainability, inclusivity, and put participatory self-help as the main function of the program. Here is the total accumulation of voluntary funds for Program Bedah Rumah Swadaya during the last four years running.

As described previously, that each of line has advantages and disadvantages. Therefore, specific mapping in related to advantages and disadvantages are needed for purposes of the program recommendations. Simply put author attempt to map out by using Strenghtness, Weakness, Opportunity, and Threats (SWOT) table. SWOT table aims to simplify the process of identification of strengths, weaknesses, opportunities, and threats of a political decision in public policy. After identifying these factors, then strategies can be developed to optimize the strengths, eliminate weaknesses, utilizes

Table 3.

SWOT Mapping Based on Each of Line

\begin{tabular}{|c|c|c|c|c|}
\hline Lines $^{\text {SWOT }}$ & Strength & Weakness & Opportunity & Threats \\
\hline $\begin{array}{l}\text { Charitable } \\
\text { based on } \\
\text { religiosity }\end{array}$ & $\begin{array}{l}\text { *More Sustainable: given } \\
\text { there are intersectional } \\
\text { visions between the } \\
\text { transcendent obligation } \\
\text { to charity understandings } \\
\text { and poverty alleviation } \\
\text { programs. } \\
\text { *This line is helpful } \\
\text { for incidental or non- } \\
\text { incidental situations. } \\
\text { For, e.g., emergency } \\
\text { disaster }\end{array}$ & $\begin{array}{l}\text { *Prone to exclusivity issues: } \\
\text { Cannot be separated from } \\
\text { primordial issues, nor the } \\
\text { political identity as well. } \\
\text { The effect is, for those who } \\
\text { deserve as beneficiaries } \\
\text { tend to based on } \\
\text { primordial considerations, } \\
\text { rather than need. }\end{array}$ & $\begin{array}{l}\text { *Resistant from the } \\
\text { economic crisis }\end{array}$ & $\begin{array}{l}\text { *Prone to identity } \\
\text { politics that could } \\
\text { potentially arise } \\
\text { conflict horizontally. }\end{array}$ \\
\hline $\begin{array}{l}\text { Company } \\
\text { approach }\end{array}$ & *adhere to inclusiveness & $\begin{array}{l}\text { *No sustainable guarantee, } \\
\text { due to CSR is carried out for } \\
\text { a certain period only in order } \\
\text { to regulatory compliance, } \\
\text { subsequently, get liaison to } \\
\text { operate. }\end{array}$ & $\begin{array}{l}\text { *Depend on } \\
\text { investment and } \\
\text { economic growth. } \\
\text { When both are good, } \\
\text { then it possible to } \\
\text { private company } \\
\text { contribute to }\end{array}$ & $\begin{array}{l}{ }^{*} \text { Economic and } \\
\text { political crises } \\
\text { would affect to fund } \\
\text { accumulation }\end{array}$ \\
\hline $\begin{array}{l}\text { Voluntarism } \\
\text { approach }\end{array}$ & $\begin{array}{l}{ }^{*} \text { Adhere to inclusiveness } \\
\text { put emphasis on } \\
\text { the functions of } \\
\text { sustainability, } \\
\text { inclusivity, and put } \\
\text { participatory self-help } \\
\text { as the main function of } \\
\text { the program }\end{array}$ & $\begin{array}{l}\text { *no sustainable guarantee, } \\
\text { because of fluctuation and } \\
\text { unpredictable reasons }\end{array}$ & $\begin{array}{l}{ }^{*} \text { It can be alternative } \\
\text { option while state } \\
\text { revoke for economy } \\
\text { reason }\end{array}$ & $\begin{array}{l}\text { *Prone to infiltration } \\
\text { of particular interest } \\
\text { will be }\end{array}$ \\
\hline
\end{tabular}

Source: by author design 
of opportunities, and overcome the threat. The following SWOT mapping it based on each of line in its function as the program pillars.

\section{Conclusion}

As depicted at the introduction, during this time, the state assumes that welfare scheme should be dealing with residual/ selective principles due economic reason. Whereas in the communitarian society context, belongingness and collectivity aspect have embedded as guiding principles for daily life. This basic principle influences their welfare preferences toward equality distributions, thus 'they perceive have a similar right to access government assistance regardless of their social-economic status' (Sumarto, 2017: 955). Such misunderstanding logic often triggers conflict between society and local government as well as conflict among society, which tend to weakens social integrations.

Nevertheless, this study has found that Program Bedah Rumah Swadaya can bridge the gap between the state and society within understanding about welfare schemes preferences through clear and simple policy design.

First, instead of as provider, the government position which only takes roles as facilitator and regulator in order to developing cooperation between the different sectors to addressing social opportunities and problems through partnerships between governments, community agencies, and the corporate sector, then linking with the donors and beneficiaries. Second, to operating the program, Hasto applied governmentality concept as his policy strategy. It can be identified from how the government uses Gentong Rembes Movement to give the impression, as if the program authentic citizen initiatives, thus foster citizen participations to involve in. Third, the authority upon beneficiaries determination is submitted to a community it self through informal consensus mechanism (musyawarah) at the grassroots level. Thus, it can prevent the horizontal conflict as well as maintain social capital at once. These are important to be considered as a recommendation on the social policy formulation and implementation in Indonesia, particularly in related to welfare distribution methods selectively. Given the fact, the role of families and communities or kinship based still prevails in providing social welfare and become social safety nets when crises occurred.

The empirical findings in this study enhance our understanding why development of social policy in Indonesia has been slow moving due the foundation of social policy building in Indonesia often does not consider non-state actors as a partner (Joedadibrata, 2012: 9; Raper, 2008: 137). Many experts (Halimatusya'diah, 2015; Meeuwisse and Swärd, 2009; Norton, Conway and Foster, 2001; Schartau, 2009; Yeboah-Asiama et.al, 2015) argue that the non-state actor may promote effectiveness and sustainability in eradicating poverty in developing countries, as well as diminish trade-off gaps between social equity and economic efficiency.

Reflecting on Kulon Progo experiences, to design and implement welfare policies as the Kulon Progo government applied. It requires at least first, political will that leads to a facilitative governance, than regulative governance (Pratikno, 2005: 234) and second, having a good understanding of the citizenship dynamics in where social policy will be designed nor implemented.

In sum, an alternative approach that has been applied on Program Bedah Rumah Swadaya this on, may represent of innovative policy to answer the welfare political challenges, then have important implications for the future practice of social policy in good governance era.

\section{Acknowledgement}

This article is modified version of my

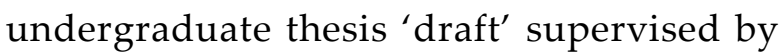
Mr. Suparjan, which I renewed partly for this 
issues. I would like to thanks for Mr. Hasto Wardoyo, Mr. Prasetyo, Mr. Mudhopati as well as those who were contributed of this project. I also benefited from the remarkable discussion with Mr. Hasrul Hanif who inspired me to using citizenship framework as a preliminary concept to understand about social policies nor welfare regimes broadly. Special remarks, I dedicate this article to my parents as my deep apologies due having to postpone my bachelor graduation for one year.

\section{References}

Aspalter, C. (2006). The East Asian welfare model. International Journal Social Welfare, 15(4), 290-301.

Baxter, P. \& Jack, S. (2008). Qualitative case study methodology: study design and implementation for novice researcher. The Qualitative Report, 13(4), 544-559.

Chan, K. H. R. (2006). Participatory welfare in South Korea: meaning and issues. CAPS Working Paper Series No.174. Retrieved from http://commons.ln.edu.hk/capswp/9

Creswell, J. W. (2013). Penelitian kualitatif dan desain riset: memilih diantara lima pendekatan. Yogyakarta: Pustaka Pelajar.

Croissant, A. (2004). Changing welfare regimes in East and Southeast Asia: Crisis, change and challenge. Social Policy $\mathcal{E}$ Administration, 38(5), 504-524.

Damsar. (2012). Sosiologi politik. Jakarta: Kencana.

Dukelow, F. (2011). Economic crisis and welfare retrenchment: comparing Irish policy responses in the 1970s and 1980s with the present. Social Policy and Administration, 45(4), 408-429.

Esping-Andersen, G. (1985). Politics against market: the social democratic road to power. Princeton, New Jersey: Princeton University Press.

Esping-Andersen, G. (1990). The three worlds of welfare capitalism. Cambridge: Polity Press.

Forum CSR Kabupaten Kulon Progo. (2015). [Dokumen Laporan Pertanggung Jawaban
Forum CSR Kabupaten Kulon Progo]. Unpublished raw data.

Gough, I. (2004). Welfare regime in development context: a global and regional analysis. In I. Gough, G. Wood, A. Barrientos, P. Bevan, P. Davis, \& G. Room, (Eds.), Insecurity and Welfare Regimes in Asia, Africa, and Latin America (pp. 15-48). Cambridge: Cambridge University Press.

Gough, I. (2013). Social policy regimes in the developing world. In K. Patricia, (Ed.), A Handbook of Comparative Social Policy (pp. 205-224). Cheltenham UK: Edward Elgar Publishing Ltd.

Gustomy, R. (2010). Negara menata umat. Yogyakarta: POLGOV UGM.

Halimatusya'diah, I. (2015). Zakat and social protection: The relationship between socioreligious CSOs and the government in Indonesia. Journal of Civil Society, 11(1), 79-99.

Hall, A., \& Migdley, J. (2004). Social policy for development. London: SAGE Publication.

Hanif, H. (2008). Mencari wajah politik masyarakat risiko (risk society): sub politik, demokrasi diskursif, dan proses kebijakan deliberatif. Jurnal Mandatory, 4(4), 74-86

Hanif, H. (2012). Dibawah bayang-bayang kewargaan pasar (market citizenship)?: menegaskan politik inklusi, mengabaikan politik redistribusi. Retrieved from http:// www.academia.edu/4503514/Dibawah_ Bayang-Bayang_Kewargaan_Pasar_ Market_Citizenship_

Heyman, J. (2012). Deepening the anthropology of bureaucracy. Anthropological Quarterly, 85(4), 1267-1277.

Hujo, K., \& McClanahan, S. (2009). Financing social policy: mobilizing resources for social development. Basingstoke: Palgrave Macmilan.

Ibrahim, S. M. (2015). The role of zakat in establishing social welfare and economic sustainability. International Journal of Management and Commerce Innovations, 3(1), 437-441. 
Ikhsanto, M. A. (2008). Dilema skema pembiayaan kebijakan sosial. In M. Ucu, (Ed.), Kebijakan Sosial dan Kesejahteraan. Yogyakarta: FISIPOL UGM.

Isin, E. F., \& Turner, B. S. (2011). Citizenship studies: An introduction. In E. F. Isin \& B. S. Turner (Eds.), Handbook of Citizenship Studies (pp. 1-10). Los Angeles: SAGE.

Joedadibrata, D. (2012). A study of the shift towards universal social policy in Indonesia. MSc Thesis. Hague: International Institute of Social Studies.

Kotchen, M. (2014). Public Goods. In J. L. Caviglia, T. C. Haab, \& J.C. Whitehead (Eds.). Environmental and natural resource economics: an encyclopedia. Santa Barbara: Greenwood.

Kurniawan, N. I. (2009). Globalisasi dan negara kesejahteraan: perspektif institutionalism. Yogyakarta: Laboratorium Jurusan Ilmu Pemerintahan, FISIPOL UGM.

Kwon, H. (2009). The reform of the developmental welfare state in East Asia. International Journal of Social Welfare, 18(1), 12-21.

Lewis, J. (Ed.). (1999). The voluntary sector in the mixed economy of welfare. In D. Gladstone (Ed.), Before Beveridge: Welfare Before the Welfare State. London: IEA Health and Welfare Unit.

Martono, U. (2008). Kebijakan sosial dan kesejahteraan. Yogyakarta: FISIPOL UGM.

Mas'udi, W., \& Hanif, H. (2010). Social welfare politics in contemporary Indonesia: understanding the social welfare vision in Act 11 of 2009 (Working Paper No.3 03/2010). Yogyakarta: PCD Press Universitas Gadjah Mada.

McClain, P. D. (1990). Agenda setting, public policy, and minority group influence: an introduction. Policy Studies Review, 9(2), 263-272.

Media Center. (2015). Kemiskinan Kulon Progo menurun. (February 2, 2016). Retrieved from http://www.kulonprogokab.go.id/v21/2015-
-Kemiskinan-Kulon-Progo-Menurun_4108

Meeuwisse, A., \& Swärd, H. (2009). Social work programmes in the social democratic welfare regime. International Journal of Social Welfare, 18(4): 365-374.

Menoh, G., A., B. (2015). Agama dalam ruang publik. Yogyakarta: Kanisius.

Moreno, L. (2010). Welfare mix, CSR and social citizenship. International Journal of Sociology and Social Policy, 30(11), 683-696. doi: 10.1108/01443331011085268

Norton, A., Conway, T., \& Foster, M. (2001). Social protection concepts and approaches: implication for policy and practice in international development. London, UK: Overseas Development Institute.

Powell, M., \& Barrientos, A. (2004). Welfare regime and welfare mix. European Journal of Political Research, 43(1), 83-105.

Pratikno. (2005). Good Governance dan Governability. Jurnal Ilmu Sosial dan Ilmu Politik, 8(3), 231-248.

Raper, M. (2008). Social security and social protection in Australia and Indonesia. Jakarta: Trade Union Right.

Rodhes, M., \& Natali, D. (2003). Welfare Regimes and Pension Reform Agendas. Retrieved from http://paperroom.ipsa.org/ papers/paper_2399.pdf

Schartau, M. (2009). The road to welfare pluralism: old age and care in Sweden, Germany, and Britain. Berlin: BWV, Berliner Wiss.-Verl.

Setda Kabupaten Kulon Progo. (2016). Daftar Penerima Bantuan Bedah Rumah Non-APBD.

Shi, S. (2016). The Bounded Welfare Pluralism: Public-Private Partnerships Under Social Management in China. Public Management Review, 19(4), 463-478. doi: 10.1080/14719037.2016.1183700

Suharko. (2005). Masyarakat sipil, modal sosial, dan tata pemerintahan yang demokratis. Jurnal Ilmu Sosial dan Ilmu Politik, 8(3), 263290.

Sumarto, M. (2007). Social safety nets and economic transition in Indonesia: Paradox 
of social services. Journal of Administration and Governance, 2(1), 54-60.

Sumarto, M. (2014). Perlindungan Sosial dan Klientelisme: Makna politik bantuan tunai dalam pemilihan umum. Yogyakarta: Gadjah Mada University Press.

Sumarto, M. (2017). Welfare regime change in developing countries: evidence from Indonesia. Social Policy and Administration, 51(6), 940-959.

Suparjan. (2010). Jaminan sosial berbasis komunitas: respon atas kegagalan negara dalam penyediaan jaminan kesejahteraan. Jurnal Ilmu Sosial dan Ilmu Politik, 13(3), 1-18.

TKPK Kulon Progo. (2014). Buku saku panduan penanggulangan kemiskinan. Wates: Pemerintah Kabupaten Kulon Progo.

TNP2K. (2011). Indikator Kesejahteraan Daerah Provinsi Daerah Istimewa Yogyakarta. Retrieved from http://www.tnp2k.go.id/ images/uploads/downloads/34_DIY.pdf

Torheim, R. (2013). Foundation of welfare regime: the case of Indonesia. Master Thesis. Oslo: Department of Political Scienes, University of Oslo.
Tribowo, D., \& Bahagijo, S. (2006). Mimpi negara kesejahteraan. Jakarta: LP3ES.

Walker, A., \& Wong, C. (2005). East Asian welfare regime in transition: from confucian to globalization. Bristol, UK: The Policy Press, University of Bristol.

Warington, M. J. (1995). Welfare plurarism or shadow state? the provision of social housing in the 1990's. Environmental and Planning, 27(1), 1341-1360.

Yeboah-Assiama, E., Musah-Suguru, I. J. N., \& Nurudeen, S. (2015). the 'third sector' and poverty reduction in developing societies: the experience of hunger project in selected rural communities of Ghana. International Journal of Rural Management, 11(2), 85-110. doi: 10.1177/0973005215601944

Yuda, T., K., (2016). Memaknai ulang corporate social responsibility: upaya mewujudkan fair responsibility. Jurnal Ilmu Sosial dan Ilmu Politik, 19(3), 200-217.

Zuska, F. (2005). Penghampiran antropologi atas kebijakan dan kekuasaan: berefleksi dari kebijakan otonomi daerah. Jurnal Antropologi Sosial Budaya ETNOVISI, 1(3), 151-158. 